\title{
Tributyltin-Induced Effects on Early Life Stages of Minnows Phoxinus phoxinus
}

\author{
Karl Fent* and Willy Meier** \\ *Swiss Federal Institute for Water Resources and Water Pollution Control (EAWAG/ETH), CH-6047 Kastanienbaum, Switzerland, and **University \\ of Berne, Institute of Animal Pathology, Länggass-Strasse 122. CH-3012 Berne, Switzerland
}

\begin{abstract}
Toxicity and histopathological effects of tributyltin chloride (TBT) were studied in early life stages of minnows Phoxinus phoxinus. Eggs and yolk sac fry (newly hatched larvae) were exposed in a static-renewal procedure to aqueous TBT concentrations ranging from 0.82 to $19.51 \mu \mathrm{g} / \mathrm{L}$ for 3 to 10 days at $16^{\circ} \mathrm{C}$ and $21^{\circ} \mathrm{C}$, respectively. Aqueous TBT concentrations were determined by capillary GC-FPD and revealed a concentration decrease during the static phase. TBT exposure led to mortality, behavioral, gross morphological and histopathological effects. In larvae, increased mortality, deformation of body axis, paralysis and opaque eyes occurred at 4.26 $\mu \mathrm{g} / \mathrm{L}$ TBT and higher both in the embryonic-larval and larval exposure. Histological changes were evident at initial TBT concentrations of 0.82 up to $19.51 \mu \mathrm{g} / \mathrm{L}$, and were more pronounced after embryonic-larval exposure than after larval exposure. Degenerative alterations occurred in skin, skeletal muscle, kidney, corneal epithelium, lens, pigment layer of the retina and choroid, retina, and CNS including spinal cord. Hydropic vacuolation of the cytoplasm and, in more pronounced cases, irreversible nuclear alterations such as pycnosis, karyorrhexis and karyolysis were also evident. Exposure to $0.82 \mu \mathrm{g} / \mathrm{L}$ TBT resulted in alterations in skin, muscle and kidney, with greater effects occurring at $21^{\circ} \mathrm{C}$ than at $16^{\circ} \mathrm{C}$. Toxicity was significantly reduced in the presence of sediment. The observed histopathological effects suggest that early life stages of fish may be negatively affected in environments that are considerably polluted by TBT.
\end{abstract}

Marine and freshwater environments have been polluted by organotins due to the use of tributyltin-containing antifouling paints on vessels. During the last few years, such antifouling paints have been regulated or banned for use in small boats in a number of countries including Switzerland, thus resulting in a decrease in contamination (Alzieu 1986; Alzieu et al. 1989; Fent and Hunn 1991). However, in boat harbors there are still considerable levels of tributyltin (TBT) present, and the widespread application of organotins in a variety of products, and their use as biocides in the protection of materials including wood, wall paints, and textiles results in contamination of municipal wastewater and sewage sludge, and subsequently of the aquatic environment (Fent and Müller 1991). Therefore, the possible ecotoxicological impact of TBT is still of concern.
Several studies showed that TBT exerts chronic toxic effects at trace concentrations of a few $\mathrm{ng} / \mathrm{L}$ to marine molluscs (Alzieu 1986; Bryan et al. 1986, 1989). Other marine species including algae (Walsh et al. 1985; Beaumont and Newman 1986) and zooplankton (U'ren 1983) are affected at concentrations of a few hundred ng/L or less (Bushong et al. 1990). Contrary to marine species, much less is known about the toxicity of TBT to freshwater species.

Tributyltin is also considerably toxic to fish. The acute toxicity of bis(tri- $n$-butyltin) oxide (TBTO) lies in the range of a few $\mu \mathrm{g} / \mathrm{L}$ (Hall and Pinkney 1985; Bushong et al. 1988; Martin et al. 1989). Very high concentrations of TBTO (nominal 5.85 $\mathrm{mg} / \mathrm{L}$ ) induced effects on red blood cells, gills, eyes, skin, and liver (epithelial cells of bile duct) in rainbow trout (Chliamovitch and Kuhn 1977). Histopathological effects in various organs were also observed after exposure to nominal concentrations of 0.32 to $10 \mu \mathrm{g} / \mathrm{L}$ TBTO in guppies and Japanese medaka (Wester et al. 1990), and effects on the liver occurred at 2.5 and $10 \mu \mathrm{g} / \mathrm{L}$ TBTO in the marine three-spined stickleback after exposure to painted panels (Holm et al. 1991). In this marine fish, no marked effects on the spawning rate or fecundity were observed, and the offsprings of exposed females developed normally.

Little is known about the effects of organotins on critical and sensitive early life stages of freshwater fish residing in environments which are still subject to considerable pollution. Longterm exposure of rainbow trout yolk sac fry to nominal concentrations of $1 \mu \mathrm{g} / \mathrm{L}$ TBT resulted in a decrease in the number of red blood cells, increase in liver weight, and hyperplasia of liver cells (Seinen et al. 1981), and a no-observable-effect concentration of nominal $40-50 \mathrm{ng} / \mathrm{L}$ was proposed (De Vries et al. 1991). The freshwater minnow Phoxinus phoxinus, studied here, resides in European rivers and alpine lakes, and may also reside in boat harbours. Investigations on fish species naturally residing in habitats that may be considerably polluted by organotins such as boat harbours are needed to assess the ecotoxicological impact, especially regarding the fact that spawning and recruitment takes place in the season where contamination is highest (Fent and Hunn 1991). The toxicity of TBT towards early life stages of Phoxinus is studied after embryonic-larval and larval exposure with emphasis on histopathological effects. Contrary to most previous studies, aqueous concentrations of TBT are determined by chemical analysis, instead of only giving nominal concentrations. Also, 


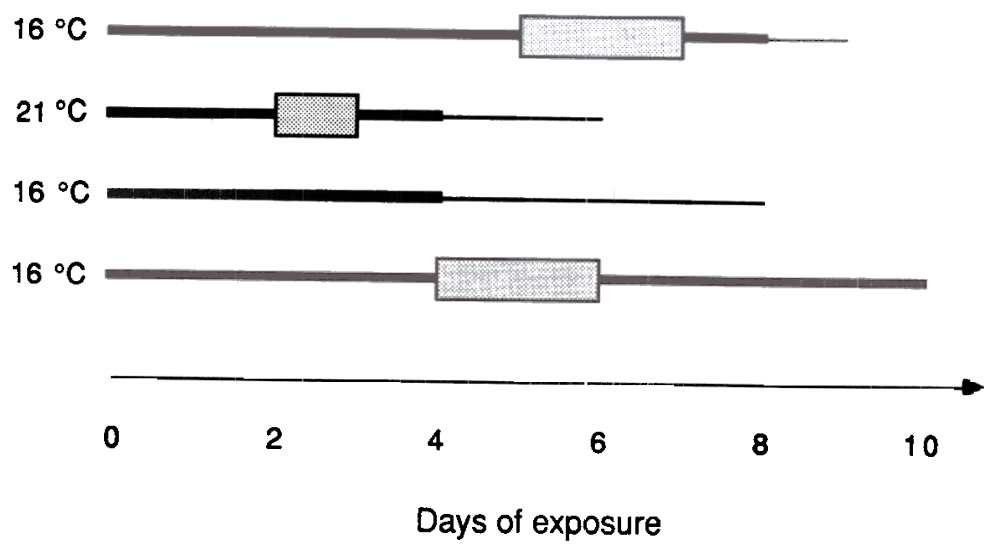

Fig. 1. Experimental design including experiment number, exposure temperature, hatching time and exposure period. Hatching period is dotted. Thin lines represent the period of the sequential end of the experiment with highest dose groups ending first; lowest dose and control groups ending last.

effects of waterborne exposure are compared with effects where Petri dishes contain both water and sediment to evaluate the influence of organotin absorption to sediment on the toxicity.

\section{Materials and Methods}

\section{Water}

Eggs and larvae were held and exposed in water from Lake Lucerne, Switzerland, which contained no detectable TBT (detection limit 2-10 $\mathrm{ng} / \mathrm{L}$ ). Dissolved oxygen and $\mathrm{pH}$ were periodically determined. During the experimental period, $\mathrm{pH}$ was in the range of 7.85 to 8.20 , oxygen in the range of 7.2 to $9.3 \mathrm{mg} / \mathrm{L}$ (70-100\% saturation), dissolved organic carbon was $0.7 \mathrm{mg} / \mathrm{L}$, and alkalinity was $0.7 \mathrm{mg} / \mathrm{L}$.

\section{Toxicant}

Tributyltin chloride ( $>97 \%$ purity) was obtained from Fluka, Buchs, Switzerland. Water from Lake Lucerne was spiked with appropriate quantities of a stock solution of TBT in acetone $(0.1 \mu \mathrm{g}$ TBT per $\mu \mathrm{l})$. Acetone was shown to be nontoxic to embryos and larvae, and no histopathological effects were observed at the concentrations used.

\section{Experimental Design}

Eggs were obtained by stripping of females followed by fertilization with milt stripped from males. Eggs from several females were pooled for each experiment, and unfertilized eggs were removed prior to exposure. Four different experiments with embryonic-larval or larval exposure were performed, as illustrated in Figure 1. In the first series of experiments, about $24 \mathrm{~h}$ after fertilization eggs were exposed in climate chambers to various concentrations of TBT. Temperatures were maintained at $16^{\circ} \mathrm{C}$ in experiment $\mathrm{I}$, and at $21^{\circ} \mathrm{C}$ in experiment II. Eggs of each exposure group were divided into three different glass Petri dishes (diameter $9 \mathrm{~cm}$, height $2 \mathrm{~cm}$ ) containing in $50 \mathrm{~mL}$ water about 30 eggs each. Eggs were exposed for 8 to 9 days to nominal concentrations of $0.89,4.5,8.9$, or $17.8 \mu \mathrm{g} / \mathrm{L}$ of tributyltin chloride (TBT) in experiment I, and to 0.89 , and $8.9 \mu \mathrm{g} / \mathrm{L}$ of TBT for 4 to 6 days in experiment II. Also, a control and solvent control (acetone) were included in each experiment. The concentrations were chosen on the basis of measured TBT concentrations in freshwater marinas. The lowest concentration matches about the highest value measured (Fent and Hunn 1991), and the other experimental concentrations may occur in runoff of areas used for the cleaning and repainting of vessels (Fent and Hunn unpublished results). To obtain larvae for experiment III, embryos were allowed to develop in lake water. About 45 newly hatched larvae (yolk sac fry) per dose group were divided into three Petri dishes (diameter $9 \mathrm{~cm}$, height $2 \mathrm{~cm}$ ) containing $50 \mathrm{~mL}$ water and exposed in a $48 \mathrm{~h}$ static-renewal procedure to nominal concentrations of $0.89,4.5,8.9$ or $17.8 \mu \mathrm{g} / \mathrm{L}$ TBT up to 8 days. Also, a solvent control was included.

In experiment I, II, and III Petri dishes contained only water to evaluate the toxicity of waterborne TBT. In experiment IV, eggs were exposed in Petri dishes containing both water and sediment to evaluate effects of TBT in the presence of sediment. As TBT is absorbed on particulates and sediment (Fent and Müller 1991; Fent and Hunn 1991), the purpose of this experiment was to evaluate the influence of the adsorption of TBT to sediment on the toxicity. Bottom sediment $(60 \mathrm{ml})$ from a pristine river was placed in Petri dishes (diameter 14 $\mathrm{cm}$, height $2 \mathrm{~cm}$ ), and about 30 eggs were placed onto the sediment surface. Eggs were exposed for 10 days to $50 \mathrm{~mL}$ water that was renewed daily and spiked with appropriate quantities of TBT to give nominal aqueous concentrations of 8.9 and $17.8 \mu \mathrm{g} / \mathrm{L}$. The sediment contained no detectable organotins (detection limit $1-3 \mathrm{ng} / \mathrm{g}$ dry sediment), the organic carbon content was in the range of $1.6-1.8 \%$, total carbon content was 3.8-3.9\%, and total nitrogen was $0.15-0.17 \%$.

Daily observations were made for mortality, behavior and general appearance. In every experiment, water was changed and renewed either after $24 \mathrm{~h}$ or $48 \mathrm{~h}$ (static-renewal procedure); no food was provided for the larvae. At the end of the experiment when approximately 10 to $20 \%$ of the initial number of larvae remained in each group, up to thirteen larvae per dose group were preserved in $10 \%$ formalin for histological investigations.

The statistical evaluation of survival data was performed by means of a $\chi^{2}$ test. Differences in survival at the end of the exposure period between controls and exposed groups were tested.

\section{Organotin Analysis}

Actual concentrations of organotins in water samples were determined at the beginning and after $24 \mathrm{~h}$ (experiments I, II), or $48 \mathrm{~h}$ exposure (experiments III, IV). Experimental water was acidified to $\mathrm{pH} \mathrm{1-2}$ and stored at $4^{\circ} \mathrm{C}$ until analysis. Water samples collected on two successive days were pooled, and $100 \mathrm{ml}$ portions were analyzed. Details of the analytical technique employing high-performance capillary gas chromatography with flame photometric detection (GC-FPD) are given by Fent and Müller (1991). Briefly, organotins were extracted using SepPak $\mathrm{C}_{18}$ cartridges (Waters) and subsequently derivatized with the Grignard reagent, ethylmagnesium bromide. After purification on silica gel, the butyltins were analyzed by GC-FPD employing a $30 \mathrm{~m}$ fused-silica column (DB-5). Quantification was based on internal standards, and results were corrected for recovery. All organotin concentrations in this paper refer to the respective ion. 
Table 1. Mean TBT concentrations $(\mu \mathrm{g} / \mathrm{L})$ in water at the beginning of the experiment $(0 \mathrm{~h})$ and before renewal of water $(24 \mathrm{~h}$ or $48 \mathrm{~h})$

\begin{tabular}{|c|c|c|c|c|}
\hline \multirow[b]{2}{*}{ Experiment } & \multirow[b]{2}{*}{ Exposure } & \multirow[b]{2}{*}{$\begin{array}{l}\text { Nominal } \\
\text { concentration }\end{array}$} & \multicolumn{2}{|c|}{ Measured concentration } \\
\hline & & & Initial & $\begin{array}{l}24 \mathrm{~h} \text { or } \\
48 \mathrm{~h}\end{array}$ \\
\hline & Embryonic-larval $\left(16^{\circ} \mathrm{C}\right)$ & $\mathbf{0}$ & & \\
\hline & Water & 0.89 & & \\
\hline & & 4.5 & & \\
\hline & & 8.9 & & \\
\hline \multirow[t]{3}{*}{ II } & Embryonic-larval $\left(21^{\circ} \mathrm{C}\right)$ & 0 & & \\
\hline & Water & 0.89 & & \\
\hline & & 8.9 & & \\
\hline \multirow[t]{5}{*}{ III } & Larval $\left(16^{\circ} \mathrm{C}\right)$ & 0 & & \\
\hline & Water ${ }^{\mathrm{b}}$ & 0.89 & & \\
\hline & & 4.5 & & \\
\hline & & 8.9 & & \\
\hline & & 17.8 & & \\
\hline \multirow[t]{3}{*}{ IV } & Embryonic-larval $\left(16^{\circ} \mathrm{C}\right)$ & 0 & & \\
\hline & Water ${ }^{b}$ and sediment & 8.9 & & \\
\hline & & 17.8 & & \\
\hline
\end{tabular}

a Not detected, detection level about $0.02 \mu \mathrm{g} / \mathrm{L}$ in a $100 \mathrm{ml}$ sample

b 48 -h static-renewal procedure

\section{Histologic Technique}

At the end of the experiment, histological investigations were carried out with larvae preserved in $10 \%$ formalin. The larvae were then embedded in paraffin, and the 4-6 $\mu \mathrm{m}$ thick sections were hematoxylin-eosin stained using standard methods (Meier and Pfister 1981). Organs and tissues were examined histopathologically in whole-body sections.

\section{Results}

\section{Organotin Concentrations}

At the beginning of each experiment, TBT concentrations were close to nominal values; however, they consistently decreased during the $24 \mathrm{~h}$ or $48 \mathrm{~h}$ exposure period to concentrations that were between 65 to $87 \%$ of the initial concentration (Table 1). In addition to TBT, trace concentrations of dibutyltin and monobutyltin were detected initially and before water renewal, suggesting their origin from impurities. Compared to exposure in water alone, the decrease in the amount of aqueous TBT was more significant in the sediment-water experiment (experiment IV). The marked decrease down to $11 \%$ of initial concentrations was due to adsorption of TBT to the sediment as documented by sediment residue analysis (Fent 1992).

\section{Mortality, Behavior, and Gross Anomalies}

Effects of TBT on hatching, survival, behavior, and gross anomalies during embryonic-larval exposure at different temperatures (experiment II), and in the presence of sediment (experiment IV) are published in a separate paper (Fent 1992). Here, data of the embryonic-larval exposure (experiment I) and larval exposure (experiment III) are given, and emphasis is placed on histopathological findings. In the embryonic-larval exposure TBT had no measurable effect on mortality during the

embryonic phase (Figure 2). However, many larvae at 4.45 and $9.96 \mu \mathrm{g} / \mathrm{L}$ TBT were unable to perform complete hatching because of weak tail movements or paralysis. As compared to controls, mortality after hatching was significantly higher $(\mathrm{P}<0.001)$ at 4.45 and $9.96 \mu \mathrm{g} / \mathrm{L}$ TBT (Figure 2). Striking macroscopic and behavioral effect including immobilization, bent body axis to either sides (lordosis and kyphosis), retarded yolk sac resorption, edema, and opaque eyes were the most important effects observed in hatched larvae. Remarkably different reactions occurred in the sediment-water experiment. At an initial concentration of $6.85 \mu \mathrm{g} / \mathrm{L}$ TBT survival was lower than in controls, but less macroscopic alterations were observed than without sediment (Fent 1992). However, mortality at $15.54 \mu \mathrm{g} / \mathrm{L}$ TBT significantly increased and behavioral and macroscopic effects occurred.

In the larval exposure, mortality was dose related (experiment III). Figure 2 shows that almost or complete mortality occurred after 4 days, 6 days, and 8 days at initial concentrations of $19.51,8.00$ and $4.26 \mu \mathrm{g} / \mathrm{L} \mathrm{TBT}$, respectively. At these doses survival was significantly lower than in controls $(\mathrm{P}<0.001)$. No differences in mortality between solvent control and the lowest TBT dose occurred, except on day 8 where mortality was significantly higher at $0.89 \mu \mathrm{g} / \mathrm{L}$ TBT $(\mathrm{P}<0.01)$. Prior to death, larvae showed erratic swimming with subsequent immobilization, and most of them developed bent tails (mainly lordosis). In addition, some larvae showed an altered yolk sac resorption, and some of them developed yolk edema. All larval eyes at 8.00 and $19.51 \mu \mathrm{g} / \mathrm{L}$ became opaque, and some opaque eyes occurred at $4.26 \mu \mathrm{g} / \mathrm{L}$ TBT.

\section{Histopathological Findings}

Degenerative alterations occurred in skin, skeletal muscle, kidney, comeal epithelium, lens, pigment layer of the retina and choroid, retina and CNS including spinal cord. Marked effects in all of these tissues and organs were found at aqueous TBT concentrations of $4.26 \mu \mathrm{g} / \mathrm{L}$ and higher. The effects on these 

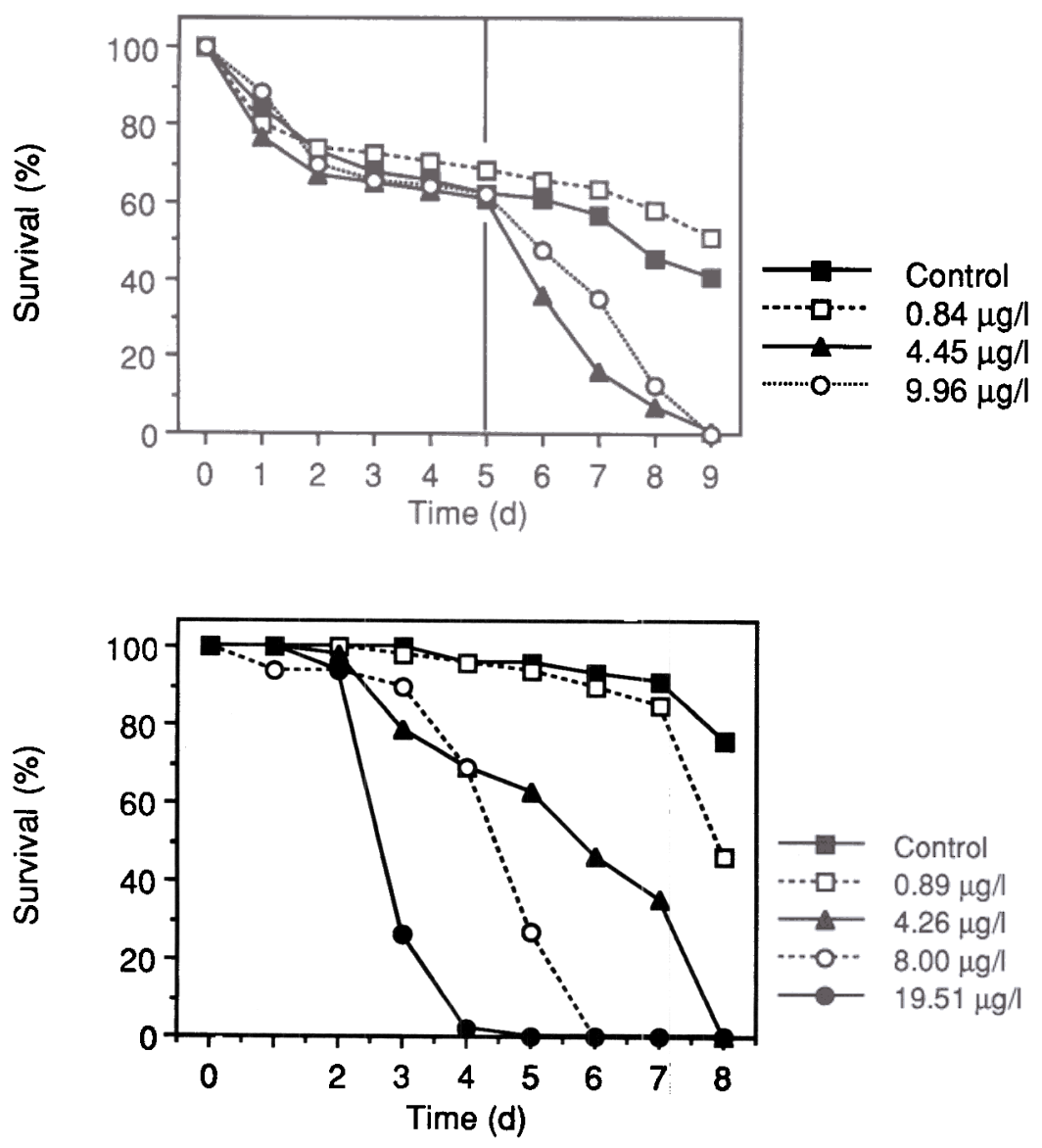

Fig. 2. Survival of minnow larvae after embryonic larval exposure (top), and larval exposure to TBT (below) at $16^{\circ} \mathrm{C}$. Vertical line on day 5 in the embryonic-larval exposure indicates start of hatching. Control and each dose group consisted of 89 to 95 embryos in the embryonic-larval exposure, and 44 to 48 larvae in the larval exposure. Survival was significantly lower at 4.45 and $9.96 \mu \mathrm{g} / \mathrm{L}$ TBT in the embryonic-larval exposure, and at all TBT concentrations in the larval exposure $(\mathrm{P}<0.01)$

organs are related to the dose. The grading of the lesions for each dose group is listed in Table 2. For each dose group, the average degree of severity in all examined larvae is given. At initial concentration of $4.26 \mu \mathrm{g} / \mathrm{L}$ TBT and higher each larva showed the histological alterations listed. Histopathological effects were similar in all the experiments and they are described in detail below. Degenerative alterations were more marked at the higher temperature, and they were more pronounced after embryonic-larval exposure than after larval exposure alone. After embryonic-larval exposure to concentrations of 0.82 $\mu \mathrm{g} / \mathrm{L}$ at $21^{\circ} \mathrm{C}$, alterations in skin, muscle and kidney were observed. However, only minor effects occurred in the sediment-water exposure, and only at the highest initial concentration $(15.54 \mu \mathrm{g} / \mathrm{L})$. In the other organs, either (1) no alterations were detected (intestine), (2) the number of histological sections were too small to examine (liver), or (3) tested larval organs were not yet adequately differentiated to allow for an accurate investigation (liver, gill).

\section{Embryonic-Larval Exposure}

Skin: Degenerative changes in the skin were dose-dependent. Minor alterations were observed at $0.84 \mu \mathrm{g} / \mathrm{L}$, moderate changes at $4.45 \mu \mathrm{g} / \mathrm{L}$, and marked changes at $9.96 \mu \mathrm{g} / \mathrm{L} \mathrm{TBT}$. In the epithelial cells of the skin, hydropic vacuolation was observed in the cytoplasm. In more pronounced cases, irreversible nuclear alterations such as pycnosis, karyorrhexis and karyolysis were also evident. These changes led to erosion or even ulceration of the epithelium (Figure 3, Figure 7).

Skeletal Muscle: Severe alterations in muscle fibres were reflected in a spectrum of degenerative changes ranging from hydropic swelling to lysis of myocytes. Myocytolysis led to a disordering of the myocytes in the myomeres and, in severe cases, adjacent myosepta were also affected (Figure 3). Alterations were dose related and ranged from splitting of muscle fibres, broken and contorted myomeres, to dislocation of the myosepta (Figure 4).

Kidney: Renal changes consisted predominantly of tubular epithelial lesions such as hydropic vacuolation and nuclear alterations. In the nuclei, pycnosis, karyorrhexis or even karyolysis were observed (Figure 5). All of these alterations were observed at concentrations as low as $4.45 \mu \mathrm{g} / \mathrm{L}$, but were most evident at $9.96 \mu \mathrm{g} / \mathrm{L}$ TBT. At $0.84 \mu \mathrm{g} / \mathrm{L}$ TBT, only hydropic vacuolation was evident.

Eye: In TBT exposed larvae, the corneal epithelium, lens, retina and pigment layer of the retina and choroid showed degenerative changes. Alterations were most severe at the highest concentration (Table 2). The external epithelial layer of the cornea, normally composed of squamous cells, was eroded and lacked structure (Figure 6). The normal ordering of retinal layers was disrupted. In the layers of the retina, single-cell necrosis and focal necrosis were observed. In the lens, vacuolation and disintegration of collagen fibers were seen. The quantity of pigment in the pigment layer of the retina and the choroid was reduced depending on the TBT dose. These changes re- 
Table 2. Histopathological alterations in larvae of Phoxinus phoxinus after embryonic-larval and larval exposure to TBT for 4 to 10 days. Rating values represent averages of all larvae in each group

\begin{tabular}{|c|c|c|c|c|c|c|c|c|c|}
\hline Experiment & $\begin{array}{l}\text { Initial } \\
\text { concn } \\
(\mu \mathrm{g} / \mathrm{L})\end{array}$ & $\begin{array}{l}\text { Number of } \\
\text { animals } \\
\text { examined }\end{array}$ & Skin & Muscles & Kidney & Cornea & Lens & $\begin{array}{l}\text { Retina/ } \\
\text { pigment }\end{array}$ & CNS \\
\hline \multirow[t]{4}{*}{ I; e, $16^{\circ} \mathrm{C}^{\mathrm{a}}$} & 0 & 13 & b & - & - & - & - & & \\
\hline & 0.84 & 6 & + & + & + & - to + & - to + & & - \\
\hline & 4.45 & 3 & ++ & ++ & $+t$ & ++ & + & + & + \\
\hline & 9.96 & 11 & +++ & +++ & $++t$ & +++ & +++ & ++ & \\
\hline \multirow[t]{3}{*}{ II; e, $21^{\circ} \mathrm{C}$} & 0 & 3 & - & - & - & - & - & - & - \\
\hline & 0.82 & 5 & ++ & + to ++ & $+t$ & + & + to ++ & + & + \\
\hline & 9.25 & 3 & +++ & +++ & +++ & +++ & +++ & +++ & +++ \\
\hline \multirow[t]{5}{*}{ III; $1,16^{\circ} \mathrm{C}$} & 0 & 11 & - & - & - & - & & - & - \\
\hline & 0.89 & & - & - & - & & - & - & \\
\hline & 4.26 & 6 & ++ & + & & + & - & & + \\
\hline & 8.00 & 6 & +++ & +++ & + & nd & nd & + to ++ & +++ \\
\hline & 19.51 & 5 & +++ & $++t$ & +++ & +++ & +++ & +++ & +++ \\
\hline \multirow[t]{3}{*}{ IV; e, $16^{\circ} \mathrm{C}, \mathrm{s}$} & 0 & 6 & - & - & & - & - & & \\
\hline & 6.85 & 8 & - & - to + & - & - & & & \\
\hline & 15.54 & 3 & + & + to ++ & nd & + & + & + & \\
\hline
\end{tabular}

${ }^{a}$ Experimental conditions (exposure, temperature): e, embryonic-larval; l, larval; s, sediment

${ }^{b}$ Coding system indicates average degree of severity in all larvae. Codes are as follows: - , no alterations; + , slight alteration;,++ moderate alteration; +++ , marked alteration; nd, not determined

sulted in the opaque color of the eyes that was observed macroscopically.

CNS and Spinal Cord: Alterations in cellular and fibrillar structures of the brain and spinal cord were pronounced in larvae exposed to $9.96 \mu \mathrm{g} / \mathrm{L}$ TBT. Severe, diffuse hydropic vacuolation occurred (Figure 7). In addition, multifocal nuclear alterations (pycnosis) were evident. No such alterations were observed at the lowest dose (Table 2).

\section{Effects at Higher Temperature}

Experiment II was carried out to determine the effects of embryonic-larval exposure at $21^{\circ} \mathrm{C}$ instead of $16^{\circ} \mathrm{C}$. At the higher temperature, degenerative alterations in skin, muscle, kidney, cornea and lens were more pronounced. At $0.82 \mu \mathrm{g} / \mathrm{L} \mathrm{TBT}$, increased vacuolation was observed in the epithelial cells of skin and in the tubular epithelium of the kidney. In addition, single-cell necrosis, or even focal necrosis were present in the brain. None of these changes were observed at $16^{\circ} \mathrm{C}$ (Table 2). These findings indicate that the toxicity of TBT is higher at elevated temperatures.

\section{Larval Exposure}

Experiment III was undertaken to compare effects of TBT on larvae with those occurring when both embryonic and larval stages were exposed. Histological changes were less pronounced in the larval exposure (Table 2 ). In both exposure regimes, the same target organs and tissues were affected, and the degenerative alterations were identical, but weaker. After larval exposure, histological alterations were absent at $\mathbf{0 . 8 9}$ $\mu \mathrm{g} / \mathrm{L}$, absent or minor at $4.26 \mu \mathrm{g} / \mathrm{L}$, moderate to marked at $8.00 \mu \mathrm{g} / \mathrm{L}$ and severe at $19.51 \mu \mathrm{g} / \mathrm{L}$ TBT. These findings indicate that the toxicity was lower in the larval exposure, at least in the concentration range of 0.89 to $4.26 \mu \mathrm{g} / \mathrm{L} \mathrm{TBT}$, in which the exposure times were identical in both exposure regimes.

\section{Sediment-Water Exposure}

The presence of sediment in the Petri dishes led to a striking reduction in toxicity in embryonic-larval exposures. This was due to a substantial reduction in aqueous TBT concentrations (Table 1). No histological changes were evident at initial concentrations of $6.85 \mu \mathrm{g} / \mathrm{L}$. Only at $15.54 \mu \mathrm{g} / \mathrm{L}$ did minor degenerative changes occur in skin, muscle, corneal epithelium, lens and retina (Table 2). These results indicate that toxic effects were dependent on the aqueous (dissolved) organotin concentration, and that adsorption of TBT to sediment reduces toxicity significantly.

\section{Discussion}

In this study, the general toxicity and histopathological effects of TBT was investigated at different exposure regimes (embryonic-larval, larval), and at different temperatures $\left(16^{\circ} \mathrm{C}, 21^{\circ} \mathrm{C}\right)$. In addition, the influence of sediment on these parameters were assessed. After embryonic-larval and larval exposure, various tissues of Phoxinus phoxinus were affected at aqueous concentrations of $0.82 \mu \mathrm{g} / \mathrm{L}$ TBT and higher. A previous study in minnow early life stages has shown that the uptake of TBT is rapid, metabolism is virtually absent, and elimination is very slow (Fent 1991), thereby indicating that the observed toxic effects can be ascribed to TBT. According to this study the incorporation of TBT increased significantly after hatching. Also, the present investigation indicates larvae being more sensitive than embryos that are protected by a chorion. Larval target organs included skeletal muscle, skin, kidney, eye and 

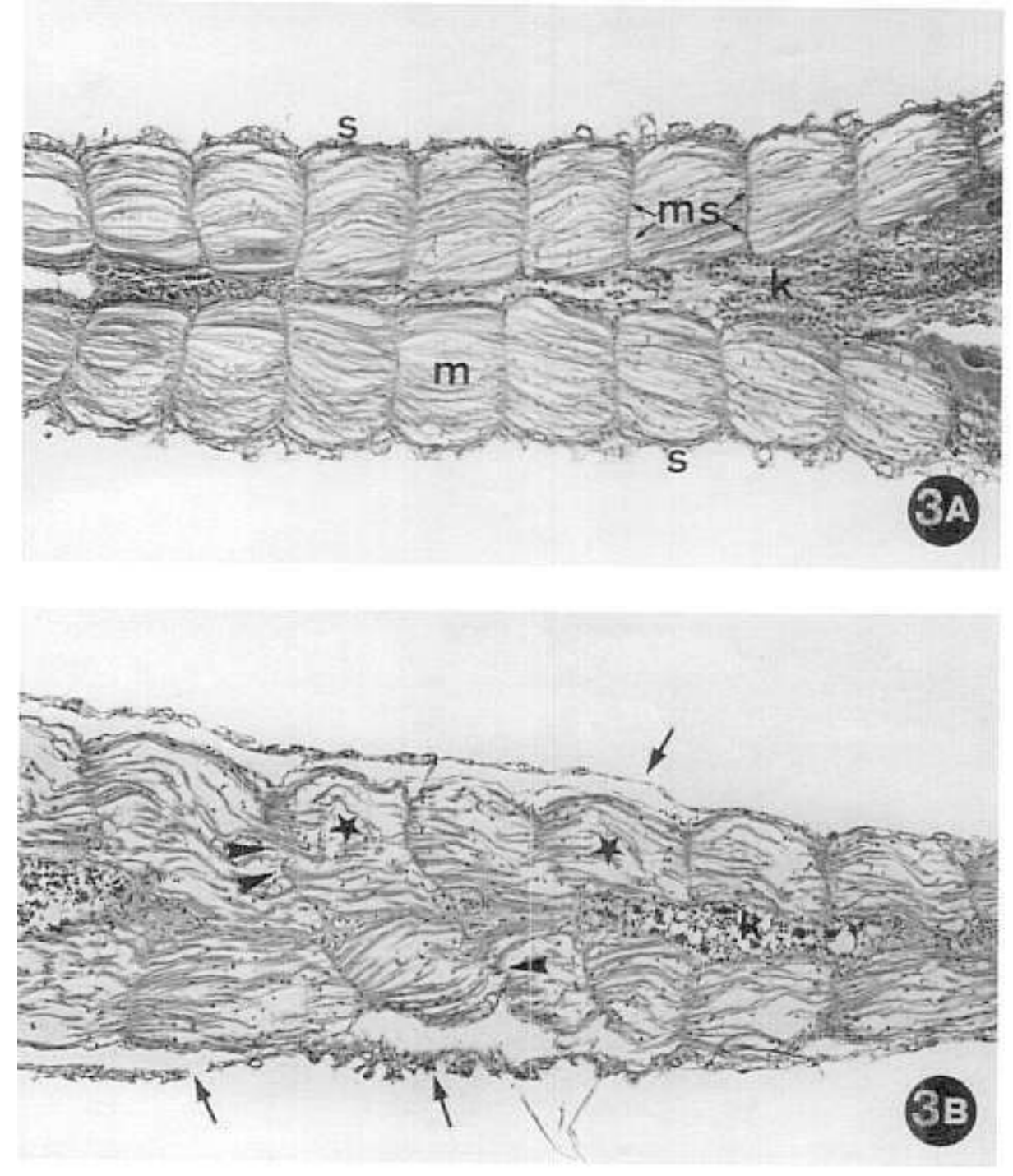

Fig. 3. Latero-lateral sections of the posterior part of a Phoxinus yolk sac fry: Skin (s); skeletal musculature (m); myosepta (ms); kidney (k). HE,

$130 \times$. (A) Control section. (B) Larva exposed to $9.96 \mu \mathrm{g} / \mathrm{L} \mathrm{TBT}$ with detachment and erosion of the epithelial layer of the skin $(\uparrow)$; complete loss of the muscle arrangement of myosepta $(\boldsymbol{\Lambda})$ and myomeres $\left({ }^{*}\right)$.

CNS. Following exposure to concentrations equivalent of those measured in polluted marinas, alterations were noted in skin, muscle and kidney after embryonic-larval exposure, particularly at higher temperatures. However, mortality at both temperatures was not different from controls (Fent 1992), indicating histopathology as a more sensitive indicator of toxicity. In the presence of sediment, TBT was absorbed from the water phase, and the reduced aqueous bioavailability of this compound correlated with the reduced toxicity. Unlike as in many previous studies with fish, here the aqueous concentrations of TBT were actually determined, instead of giving nominal values or estimations of actual concentrations. Data of the chemical analysis emphasize that the determination of actual concentrations during exposure is important. This is not only crucial for the assessment of the ecotoxicity of environmental pollutants, but also for the determination of no-observed-effect-levels.

The reported results on mortality are consistent with those in other fish where acute toxicity occurred at a few $\mu \mathrm{g} / \mathrm{L}$ (Hall and Pinkney 1985; Bushong et al. 1988). In rainbow trout a $\mathrm{LC}_{50}$ of $1.41 \mu \mathrm{g} / \mathrm{L}$ (as Sn) was determined (Martin et al. 1989). In Phoxinus yolk sac fry, mortality was increased at $0.89,4.26$ $\mu \mathrm{g} / \mathrm{L}$ (as TBT ion) and above, which is in the same range of the acute toxicity found in rainbow trout yolk sac fry (De Vries et al. 1991). Some of the observed histologic alterations induced by tributyltin chloride were previously described in fish, but others were identified here for the first time. Among the latter are alterations in skeletal muscle and in the CNS including spinal cord. Fish target organs and tissues already described to be affected by TBTO include, among others, skin, cornea, neural retina layers, pigment layer of the retina, and kidney tubular cells (Chliamovitch and Kuhn 1977; Wester and Canton 1990). Depletion of glycogen in liver cells was found after exposure to di- and trialkylated organotins in rainbow trout larvae (De Vries et al. 1991).

Desquamation in skin and cornea are attributed to the irritative property of TBT. Lesions of the cornea similar to those observed in the present study were found in rainbow trout (Chliamovitch and Kuhn 1977). Corneal keratitis and increased vacuolation as well as dermal hyperplasia occurred in guppies and in medaka (Wester and Canton 1990). In yolk sac fry of Phoxinus, gills and other organs were not fully developed therefore, a histological investigation was difficult or impossible. Gills are frequently affected by irritating compounds, as 

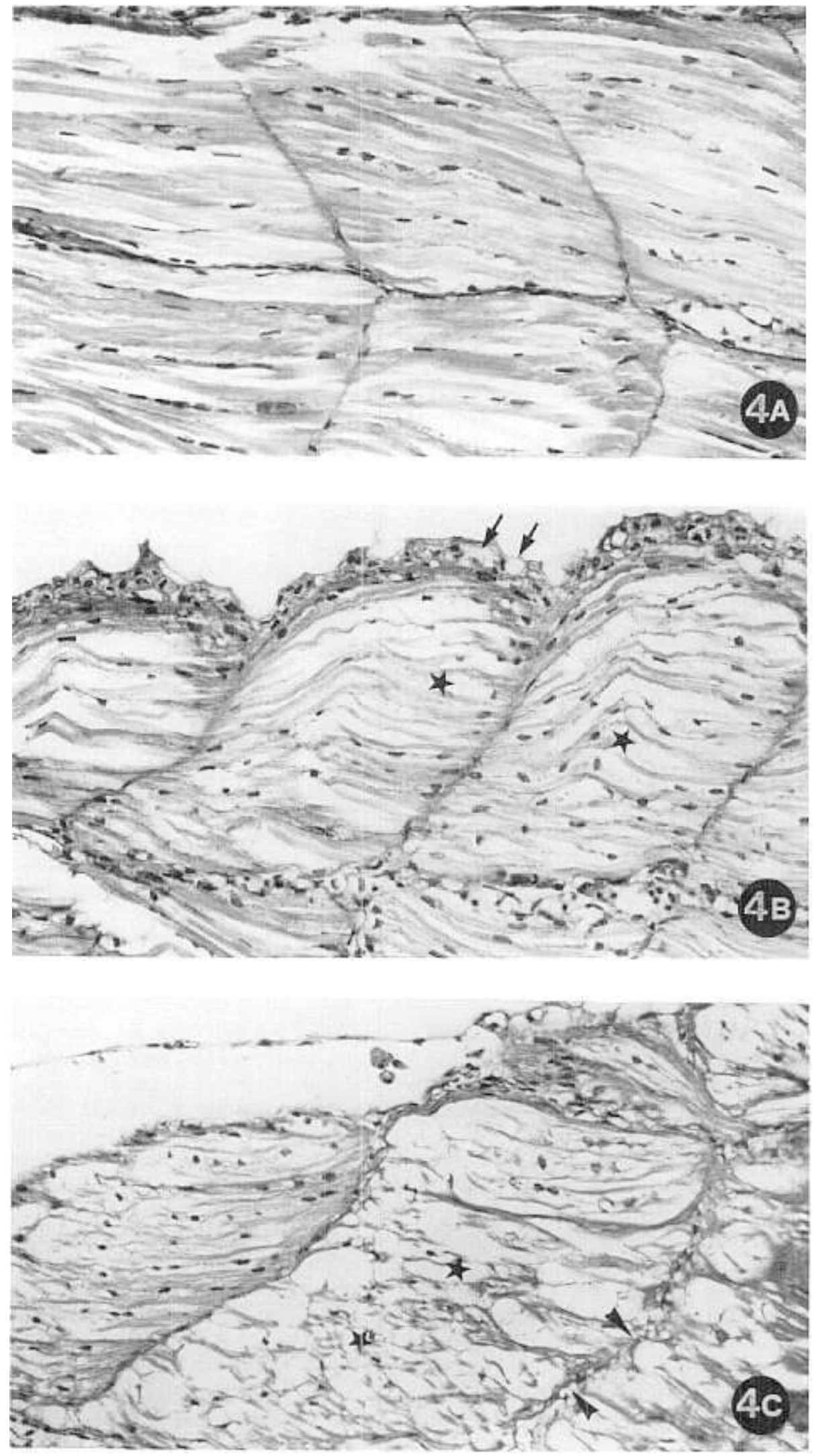

Fig. 4. Dorso-lateral sections of the musculature behind the dorsal fin. HE, $330 \times$. (A) Control section. (B) Fish exposed to $4.45 \mu \mathrm{g} / \mathrm{L}$ TBT. Moderate loss of the myomeric pattern (*); hydropic vacuolation of the skin ( $\uparrow$ ). (C) Fish exposed to $9.96 \mu \mathrm{g} / \mathrm{L}$ TBT. Contorted myomeres $(*)$ and dislocated myosepta (A) 

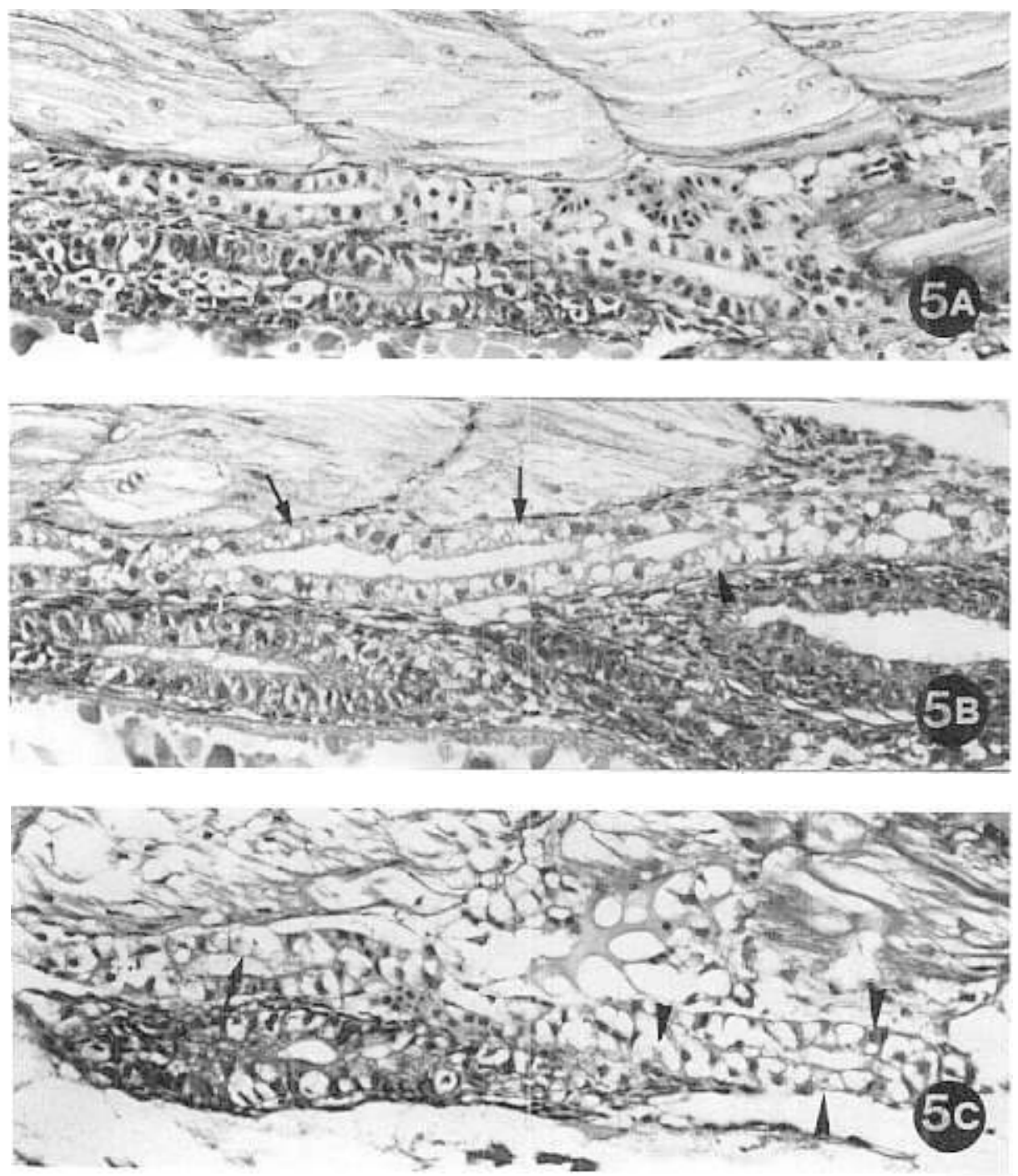

Fig. 5. Posterior kidney of minnow larvae. HE, $330 \times$. (A) Control section. (B) Larva exposed to $4.45 \mu \mathrm{g} / \mathrm{L}$ TBT. (C) Larva exposed to $9.96 \mu \mathrm{g} / \mathrm{L}$ TBT. Epithelial cells of the tubules show irregularly vacuolated $(\uparrow)$ cytoplasm and pyknotic $(\boldsymbol{\Lambda})$ or completely destroyed (४) nuclei (karyolysis)

was true for rainbow trout (Chliamovitch and Kuhn 1977), but not for guppies (Wester and Canton 1987). In the threespined stickleback considerable changes in gill structure occurred at 10 , but not at 0.1 or $2.5 \mu \mathrm{g} / \mathrm{L}$ TBTO (Holm et al. 1991). The erosion of the body surface epithelia of Phoxinus yolk sac fry led to a subsequent loss of the epithelial barrier. As a consequence, osmoregulative problems arose which led to hydropic cell alterations in the whole body of larvae, and probably also to a more effective incorporation of TBT. The opaque color of the eyes observed in TBT-exposed larvae was due to alterations of the cornea, lens and retinal pigment layer. Opaque eyes were observed in embryos prior to hatching, thereby indicating that cytotoxicity occurred already during embryonic development. Pollutant-induced cataracts were also reported in fish exposed to sediment-borne contaminants (Hargis and Zwerner 1989). Effects on the kidney similar to those observed here in minnows were described after long-term exposure to nominal 3.2 up to $10 \mu \mathrm{g} / \mathrm{L}$ TBTO in guppy, and tubulonephrosis was also observed in medaka (Wester and Canton 1990).
The most striking effects in this study, not reported in previous studies, were changes in muscle tissues at concentrations higher than $4.26 \mu \mathrm{g} / \mathrm{L}$. They also occurred at $0.82 \mu \mathrm{g} / \mathrm{L} \mathrm{TBT}$ at the higher temperature. In the embryonic-larval exposures, hatched larvae with disorientation and destruction of myotomal structure and severe myocytoloysis were motionless at 4.45 $\mu \mathrm{g} / \mathrm{L}$ and higher concentrations (Fent 1992); paralysis also occurred in larval exposure. Neurotoxicity of TBT as observed in brain and spinal cord of Phoxinus has not been described previously in fish. However, other organotins such as triethyltin and trimethyltin have been shown in mammals and man to be neurotoxic (Stoner et al. 1955; Brown et al. 1984). In the embryonic-larval exposure at initial TBT concentrations of $4.45 \mu \mathrm{g} / \mathrm{L}$ and higher, Phoxinus larvae remained motionless at the bottom of the Petri dishes, or they were only able to perform contractions of the tail, or they swam in an uncoordinated manner after hatching. This behavior might result from effects on muscle or nervous tissue, or both.

In conclusion, the toxicity of TBT in minnow early life stages is based on its eye- and skin-irritative activity, and on its 

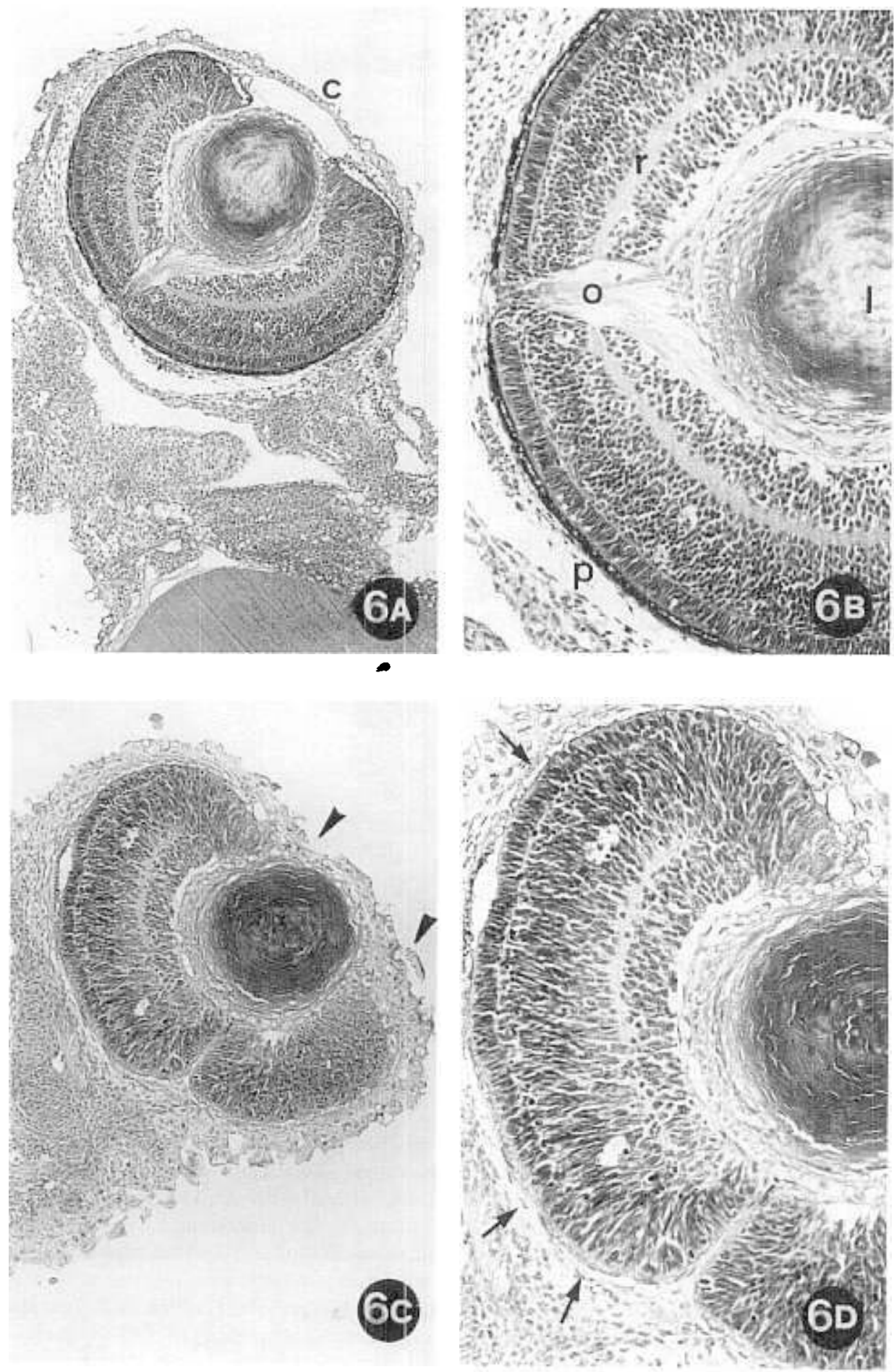

Fig. 6. Eyes of minnow larvae. $\mathrm{HE}, 130 \times(\mathrm{A}, \mathrm{C}) ; 330 \mathrm{X}(\mathrm{B}, \mathrm{D})$. $(A, B)$ Control section: $\mathrm{c}$, corneal epithelium; l, lens; $r$, retina; $o$, optic nerve; $\mathrm{p}$, pigment layer. (C,D) Fish exposed to $9.96 \mu \mathrm{g} / \mathrm{L}$ TBT. Marked depigmentation $(\uparrow)$, irregular arrangement of the retina, degenerative alterations in the lens and erosion of the corneal epithelium ( $\mathbf{\Delta})$ activity against muscular, renal and neuronal tissues. Of particular importance are effects on skin, skeletal muscle and kidney at concentrations close to those measured in boat harbors, where a peak value of $0.75 \mu \mathrm{g} / \mathrm{L}$ TBT was measured (Fent and Hunn 1991). The histologic alterations, induced after shortterm exposure, will be more harmful after long-term exposure, and might impair reproductive success of sensitive fish species via larval toxicity in heavily impacted areas.
Acknowledgment. We thank J. Hunn and R. Lovas, EAWAG/ETH, for assistance during the performance of the experiments.

\section{References}

Alzieu C (1986) TBT detrimental effects on oyster culture in FranceEvolution since antifouling paint regulation. In: Oceans '86 Or- 

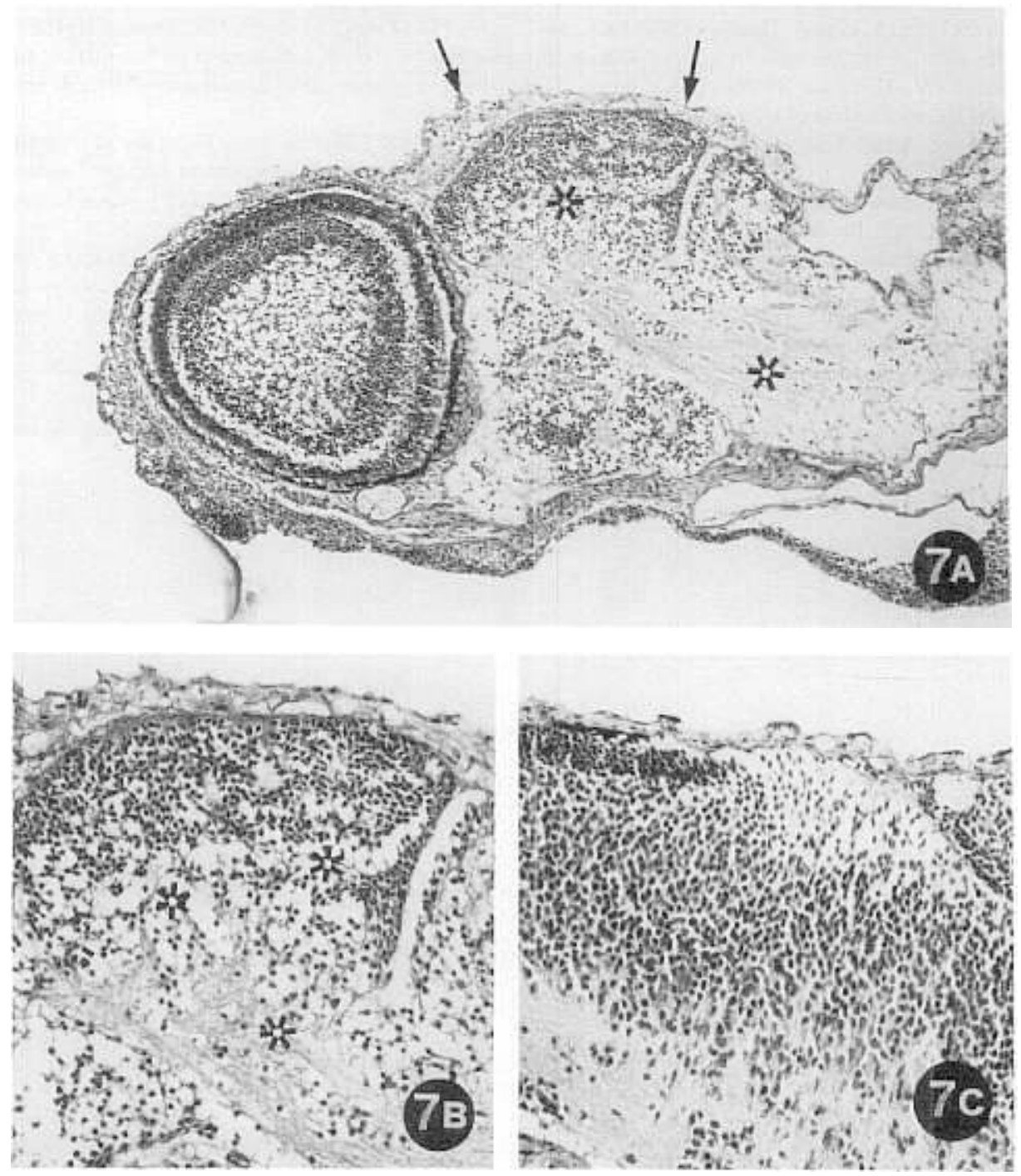

Fig. 7. Sagittal section of the brain of minnow larvae. $\mathrm{HE}, 130 \times(\mathrm{A})$. $300 \times(B, C)$. (A, B) Fish exposed to $8.00 \mu \mathrm{g} / \mathrm{L}$ TBT. Marked hydropic vacuolation of all parts of the poorly differentiated central nervous system $\left(^{*}\right)$; hydropic alterations of the skin ( $\uparrow$. (C) Control section ganotin Symposium Conference Proceedings. Marine Technology Society, IEEE, Washington, DC, Vol. 4, pp 1130-1134

Alzieu C, Sanjuan J, Michel P, Borel M, Dreno JP (1989) Monitoring and assessment of butyltins in Atlantic coastal waters. Mar Pollut Bull 20: 22-26

Beaumont AR and Newman PB (1986) Low levels of tributyltin reduce growth of marine micro-algae. Mar Pollut Bull 17: 457-461

Brown AW, Verschoyle RD, Street BW, Aldridge WN, Grindley H (1984) The neurotoxicity of trimethyltin chloride in hamsters, gerbils and marmosets. J Appl Toxicol 4: 12-21

Bryan GW, Gibbs PE, Hummerstone LG, Burt GR (1986) The decline of the gastropod Nucella lapillus around south-west England: evidence for the effect of tributyltin from antifouling paints. J Mar Biol Assoc UK 66: 611-640

Bryan GW, Gibbs PE, Huggett RJ, Curtis LA, Bailey DS, Dauer DM (1989) Effects of tributyltin pollution on the mud snail, Ilyanassa obsoleta, from the York River and Sarah Creek, Chesapeake Bay. Mar Pollut Bull 20: 458-462

Bushong SJ, Hall LW Jr, Hall WS, Johnson WE, Herman RL (1988) Acute toxicity of tributyltin to selected Chesapeake Bay fish and invertebrates. Wat Res 22: 1027-1032

Bushong SJ, Ziegenfuss MC, Unger MA, Hall LW Jr (1990) Chronic tributyltin toxicity experiments with the Chesapeake Bay copepod, Acartia tonsa. Environ Toxicol Chem 9: 359-366
Chliamovitch YP, Kuhn C (1977) Behavioural, haematological and histological studies on acute toxicity of bis(tri-n-butyltin) oxide on Salmo gairdneri Richardson and Tilapia rendalli Boulenger. J Fish Biol 10: 575-585

De Vries H, Penninks AH, Snoeij NJ, Seinen W (1991) Comparative toxicity of organotin compounds to rainbow trout (Oncorhynchus mykiss) yolk sac fry. Sci. Total Environ 103: 229-243

Fent K (1991) Bioconcentration and elimination of tributyltin chloride by embryos and larvae of minnows Phoxinus phoxinus. Aquatic Toxicol 20: 147-158

(1992) Embryotoxic effects of tributyltin on the minnow Phoxinus phoxinus. Environ Pollut (in press).

Fent K, Müller MD (1991) Occurrence of organotins in municipal wastewater and sewage sludge and behavior in a treatment plant. Environ Sci Technol 25: 489-493

Fent K, Hunn J (1991) Phenyltins in water, sediment and biota of freshwater marinas. Environ Sci Technol 25: 956-963

Hall LW Jr, Pinkney AE (1985) Acute and sublethal effects of organotin compounds on aquatic biota: An interpretative literature evaluation. CRC Crit Rev Toxicol 14: 159-209

Hargis WJ, Zwerner DE (1989) Some effects of sediment-borne contaminants on development and cytomorphology of teleost eyelens, epithelial-cells and their derivatives. Mar Environ Res 28: 399-405 
Holm G, Norrgren L, Lindén, O (1991) Reproductive and histopathological effects of long-term experimental exposure to bis(tributyltin) oxide (TBTO) on the three-spined stickleback, Gasterosteus aculeatus Linnaeus. J Fish Biol 38: 373-386

Martin RC, Dixon DG, Maguire RJ, Hodson PV, Tkacz RJ (1989) Acute toxicity, uptake, depuration and tissue distribution of tri-nbutyltin in rainbow trout, Salmo gairdneri. Aquat Toxicol 15: 37-52

Meier W, Pfister K (1981) Viral hemorrhagic septicemia (VHS) in pike (Esox lucius L.): Clinical, macroscopic, histological and elecronmicroscopical findings. Direct visualization of the Estven-virus. Schweiz Arch Tierheilk 123: 27-49

Seinen W, Helder T, Vernij H, Penninks A. Leeuwangh P (1981) Short term toxicity of tri-n-butyltin chloride in rainbow trout (Salmo gairdneri Richardson) yolk sac fry. Sci Total Environ 19: 155-166

Stoner HB, Farnes JM, Duff JI (1955) Studies on the toxicity of alkyl tin compounds. $\mathrm{Br} J$ Pharmacol 10: 16-25
U'ren SC (1983) Acute toxicity of bis(tributyltin) oxide to a marine copepod. Mar Pollut Bull 14: 303-306

Walsh GE, McLaughlan LL, Lores EM, Louie MK, Deans CH (1985). Effects of organotins on growth and survival of two marine diatoms, Skeletonema costatum and Thalassiosira pseudonata. Chemosphere 14: 383-392

Wester PW, Canton JH (1987) Histopathological study of Poecilia reticulata (guppy) after long-term exposure to bis(tri-n-butyltin) oxide (TBTO) and di- $n$-butyltindichloride (DBTC). Aquat Toxicol 10: $143-165$

(1990) The toxicity of bis(tri-n-butyltin) oxide (TBTO) and di- $n$-butyltindichloride (DBTC) in the small fish species Oryzias latipes (medaka) and Poecilia reticulata (guppy). Aquat Toxicol 16: $53-72$

Manuscript received September 25, 199I and in revised form Decem ber 16, 1991. 